\title{
PENYULUHAN TEKNIK PENGOLAHAN UREA MINERAL MOLLASES BLOK DI KELOMPOK TERNAK SUMBER REZEKI KARYA TANI KECAMATAN LANDASAN ULIN KOTA BANJARBARU KALIMANTAN SELATAN
}

\section{Counseling on Urea Mineral Block Mollases Processing Techniques in Livestock Group Sources of Rezeki Karya Tani, Landasan Ulin District, Banjarbaru City, South Kalimantan}

\author{
Dharmawati, $\mathbf{S}^{1 *}$, Sugiarti, ${ }^{1)}$ Nurhasanah $^{2)}$ \\ ${ }^{1)}$ Jurusan Peternakan, Fakultas Pertanian, Universitas Islam Kalimantan MAB, Banjarmasin \\ ${ }^{2}$ FKIP, Universitas Islam Kalimantan MAB, Banjarmasin
}

Article history

Received: Jul 1, 2020;

Accepted: Okt 20, 2020

* Corresponding author:

E-mail:

dharmauniska@gmail.com

DOI: https://doi.org/10.465

49/igkojei.v1i1.120

\section{ABSTRACT}

The partners involved in Community Service (P2M) are Sumber Rezeki Karya Tani Farmer Groups domiciled in the Landasan Ulin Timur Subdistrict, Landasan Ulin Subdistrict, Banjarbaru City, South Kalimantan. Problems faced farmers group are: (1) Farmers are very dependent on the availability of forage feed but the availability is very limited and not proportional to the amount of feed consumption per cow which is quite high (10\% of body weight). (2) Lack of dissemination and innovation by farmers to utilize and process local feed ingredients and waste feed. (3) In general, farmers do not provide supplements to cattle for growth promoters so that with these conditions the beef cattle fattening period becomes longer (> 6 months). The purpose of this activity is to help cattle farmers to increase productivity by utilizing the feed-materials and processed materials in the form of urea mollases mineral block. The method of activities includes the provision of materials and direct practice of making urea mollases mineral block UMMB then at the end of the activity an evaluation is carried out on the Farmer Group.Results of activities After the community service activity $(P 2 m)$ was carried out $90-100 \%$ of the members of the farmer group played an active role during the activity, 75-85\% understood how to properly process the mineral urea block molasses and 50\% planned to continue implementing the UMMB technology.

Keywords: Processing, Feed; Landasan Ulin Timur; Banjarbaru

\section{ABSTRAK}

Mitra yang dilibatkan pada Pengabdian Pada Masyarakat (P2M) adalah Kelompok Tani Sumber Rezeki Karya Tani berdomisili di Kelurahan Landasan Ulin Timur, Kecamatan Landasan Ulin, Kota Banjarbaru Kalimantan Selatan. Permasalahan yang dihadapi adalah: (1) Peternak sangat tergantung dengan ketersediaan pakan hijauan namun ketersediaannya sangat terbatas dan tidak sebanding dengan jumlah konsumsi pakan per ekor sapi yang cukup tinggi (10\% dari berat badan). (2) Kurangnya diseminasi dan inovasi peternak untuk memanfaatkan dan mengolah bahan-bahan pakan lokal dan pakan limbah. (3) Pada umumnya peternak tidak memberi suplemen pada sapi untuk pemacu pertumbuhan sehingga dengan kondisi tersebut masa penggemukkan sapi potong menjadi lebih lama (> 6 bulan). Tujuan kegiatan ini adalah membantu peternak untuk meningkatkan produktivitas sapi dengan memanfaatkan bahan-bahan pakan dan diolah dalam bentuk urea mineral molases blok (UMMB). Metode kegiatan meliputi pemberian materi dan praktek langsung pembuatan UMMB kemudian pada akhir kegiatan dilakukan evaluasi pada kelompok tani. Hasil 
kegiatan adalah 90-100\% dari anggota kelompok tani berperan aktif selama kegiatan berlangsung, 75-85 \% memahami cara pengolahan UMMB dengan baik dan $50 \%$ berencana melanjutkan penerapan teknologi UMMB tersebut.

Kata Kunci: Pengolahan; Pakan; Landasan Ulin Timur; Banjarbaru

\section{PENDAHULUAN}

Kelurahan Landasan Ulin Timur mempunyai ciri khas yaitu pertanian hortikultura dengan mata pencaharian utama penduduknya adalah petani dan peternak. Cikal bakal berdirinya Kelompok Tani Sumber Rezeki Karya Tani diawali aspirasi dari anggota yang ada di Kelurahan Landasan Ulin Timur yang berjumlah 20 orang. Pembentukan kelompok ini pada tanggal 1 Juli 2007 dengan kegiatan utama adalah bertani dan beternak sapi potong (Anonim, 2018). Dipilihnya ternak sapi potong karena dianggap merupakan ternak yang sangat potensial untuk dikembangkan. Saat ini populasi sapi di kelompok ini sebanyak 200 ekor dan kambing sebanyak 400 ekor. Adapun jumlah kandang yang dimiliki sebanyak 4 unit kandang kelompok dimana masing-masing unit berukuran $10 \mathrm{~m}$ x $20 \mathrm{~m}$. Selain itu kelompok ini sudah mampu membeli tanah untuk umbaran sapi seluas 10 Ha di Desa Pengaron Kabupaten Banjar. Saat ini penggemukkan ternak sapi potong dianggap jauh lebih menguntungkan mengingat permintaan sapi potong di Kalimantan Selatan cukup tinggi. Populasi sapi meningkat dari 130.691 ekor tahun 2018 menjadi 162.796 ekor pada tahun 2019, dengan jumlah permintaan daging sapi $6.747 .539 \mathrm{~kg}$ dengan rata kenaikan permintaan 14\%/tahun. Rataan pemotongan sapi potong di Kalimantan selatan 5,89\%/tahun, konsumsi protein hewani asal daging 10,53\%/tahun dengan jumlah konsumsi protein hewani asal sapi per kapita 2,61 kg/tahun (Anonim, 2019).

Permasalahan yang dihadapi oleh kelopok tani ini adalah: (1) Peternak sangat tergantung pada pakan hijauan, diaman ketersediaannya sangat terbatas dan tidak sebanding dengan jumlah konsumsi pakan per ekor sapi yang cukup tinggi (10\% dari berat badan). (2) Kurangnya diseminasi dan inovasi peternak untuk memanfaatkan dan mengolah bahan-bahan pakan lokal dan pakan limbah. (3) Pada umumnya peternak tidak memberi suplemen pada sapi untuk pemacu pertumbuhan sehingga masa penggemukkan sapi potong menjadi lebih lama ( $>6$ bulan).

Salah satu cara yang ditawarkan dalam kegiatan pengabdian ini adalah dengan pemberian UMMB. Penambahan suplemen UMMB telah lama digunakan untuk sapi potong, domba maupun kambing (Evitayami et al., 2004). Tujuan pemberian UMMB adalah sebagai aditif atau suplemen pada ternak ruminansia dengan tujuan untuk membentuk asam amino yang dibutuhkan oleh ternak ruminansia, membantu meningkatkan kecernaan dengan cara menstabilkan kondisi keasaman $(\mathrm{pH})$ rumen. Menurut Nista et al.. (2010) UMMB merupakan pakan tambahan (suplemen) untuk ternak ruminansia, berbentuk padat yang kaya dengan zat-zat makanan. Bahan pembuat UMMB antara lain adalah urea, molases, mineral dan bahan lainnya yang memiliki kandungan protein dan mineral yang cukup tinggi. Suplemen UMMB dibuat dalam bentuk padat, kompak dan keras tetapi larut dalam air sehingga memudahkan ternak untuk menjilatinya (Focus, 2005).

Teknologi pembuatan UMMB dapat diaplikasikan pada wilayah-wilayah dengan sumber pakan utamanya sangat terbatas atau kualitasnya nutrisinya rendah. Teknologi pembuatan UMMB yang mudah serta biaya yang murah dapat dilakukan oleh peternak ruminansia skala kecil (Hennessy, 1984). Suplemen UMMB dapat dibuat dengan menggunakan formulasi yang bervariasi tergantung pada pasokan dan harga bahan-bahan yang dibutuhkan. Menurut Yanuartono et al. (2015) pemberian UMMB akan meningkatkan pertumbuhan ternak dan memiliki palatabilitas tinggi sehingga disukai oleh ternak ruminansia (Yanuartono et al., 2015).

\section{METODE}

\section{PELAKSANAAN KEGIATAN}

Pengabdian pada masyarakat ini dilaksanakan di Kelompok Tani Sumber Rezeki Karya Tani Kelurahan Landasan Ulin Timur, Kecamatan Landasan Ulin, Kota Banjarbaru Kalimantan Selatan. 
Kegiatan dilaksanakan dari bulan Oktober 2019 sampai dengan bulan Januari 2020.

Kegiatan dilaksanakan dalam bentuk bimbingan teknis dari cara pemeliharaan sampai dengan bimbingan pengolahan pakan. Metode kegiatan yang dilaksanakan untuk mengatasi persoalan mitra adalah: (1) Pelatihan teoritis (metode kelas) teknik pemeliharaan sapi potong secara umum (pengenalan bibit, sistem perkandangan, metode pemberian ransum dan penanganan penyakit). (2) Praktek langsung yang dilaksakanakan oleh mitra dengan bimbingan tim (Gambar 1) dan (3) Penerapan teknologi UMMB

Dilakukan evaluasi kegiatan keberhasilan program P2M dengan indikator sebagai berikut (1) Mampu memilih bahan-bahan pakan yang berkualitas (2) Mampu membuat UMMB (3) Sapi potong yang dipelihara mitra memperlihatkan peningkatan produksi Sebelum dan setelah pelaksanaan kegiatan, peternak diminta untuk mengisi kuesioner dengan tujuan mengetahui tingkat pemahaman peternak tentang tata cara pengolahan pakan sebelum dan setelah kegiatan. Hasil ditabulasi dan dianalisis dengan metode deskriptif (Nazir, 1988).

\section{PROSEDUR PEMBUATAN UMMB/TEKNIK DINGIN}

Prosedur dilakukan dengan cara: Menimbang semua bahan - Tetes \& urea dimasukkan wadah, diaduk \pm 5-10 menit sampai urea larut - Memasukkan garam \& mineral + air sedikit, diaduk \pm 3 menit - Memasukkan semen, bentonit, diaduk sampai rata - Pencetakan - Diangin-anginkan.

Formula bahan: Mineral 20\%; Garam 5\%; Molasses 30\%; Urea 5\%; Bentonit/semen putih 10\%; Dedak/Jagung(sumber energi lain) 30\%. Peralatan: timbangan,ember,alat pengaduk dan cetakan
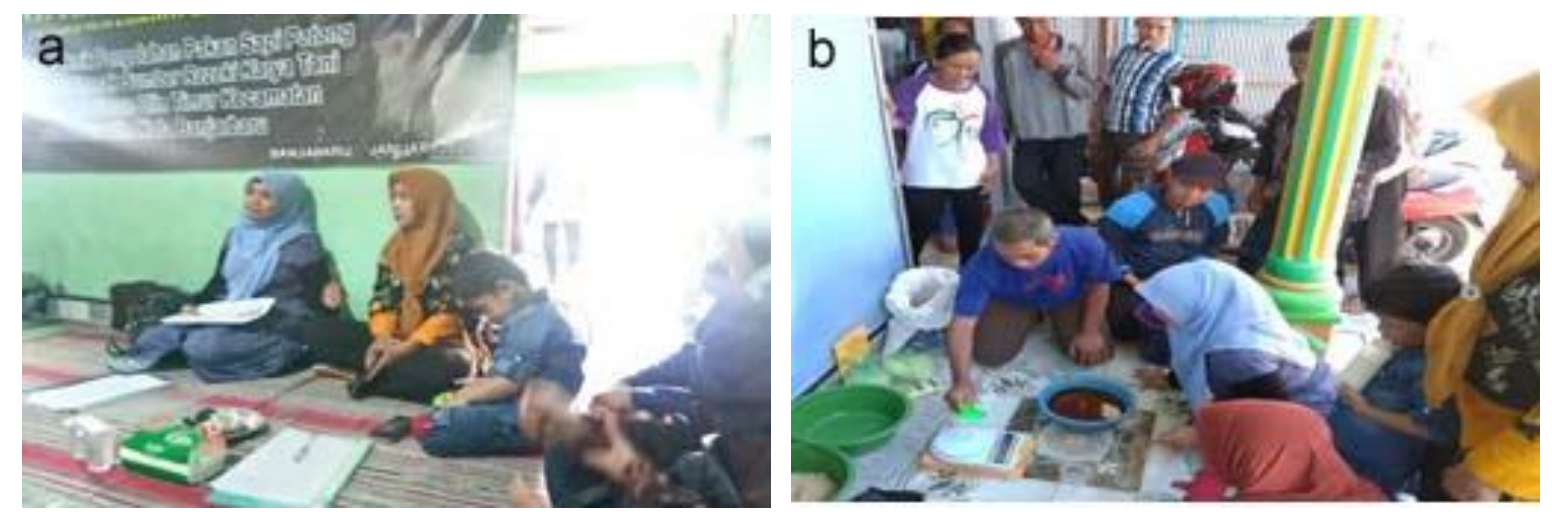

Gambar 1. Pelaksanaan kegiatan P2M. (a) Pemberian materi kegiatan; (b) Pelaksanaan praktek pembuatan UMMB

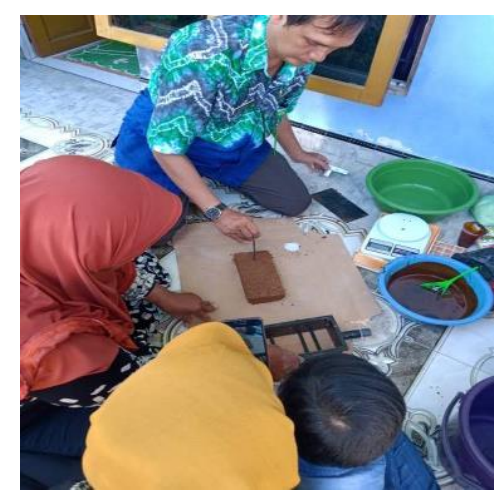

Gambar 2. Urea mineral molases blok yang dihasilkan

\section{HASIL DAN PEMBAHASAN}

\section{Kegiatan PENGABdian PADA MASYARAKAT}

Mitra yang terlibat dalam kegiatan ini berjumlah 20 orang. Mata pencaharian utama anggota kelompok adalah bertani dan beternak (90\%), buruh $(5 \%)$ dan berdagang (5\%). Rata-rata pendidikan mitra adalah SMA (18 orang/90\%), SMP (1 orang/5\%) dan SD (1 orang/5\%). 
Kegiatan P2M ini telah dilaksanakan melalui beberapa tahapan, yaitu sebagai berikut:

a. Penyampaian materi mengenai pemeliharaan sapi potong, (pengenalan bibit, sistem perkandangan, metode pemberian ransum dan penanganan penyakit); Pengenalan metode penggemukkan sapi potong; Teknik pengolahan dan pengawetan pakan hijauan khususnya pengolahan dan pengawetan pakan komplit dan Penanganan bau yang ditimbulkan dari limbah peternakan.

b. Diskusi permasalahan-permasalahan yang dihadapi oleh peternak dan cara mengatasinya.

Masalah yang berkembang dalam kegiatan diskusi yaitu: Cara memilih bahan penyusun UMMB; Teknik pengolahan UMMB; Jumlah atau dosis pemberian pada ternak sesuai fase umur dan Cara pemberian UMMB

\section{TINGKAT PARTISIPASI, HASIL UMMB DAN TINGKAT PEMAHAMAN PESERTA}

Selama penyuluhan dan bimbingan peserta sangat antusias dalam mengikuti kegiatan dari kegiatan yang sifatnya teoritis sampai ke pelaksanaan praktek pembuatan UMMB. Rata-rata tingkat kehadiran peserta adalah 90-100\%. Selain itu peserta cukup aktif bertanya dan memberikan umpan balik setiap materi yang disampaikan oleh tim P2M.

Berdasarkan formula bahan seperti tersebut di atas, UMMB yang dihasilkan memiliki kepadatan dan kekerasan yang cukup ideal (Gambar 2) setelah beberapa kali diuji coba oleh tim P2M. Menurut Yanuartono et al. (2019) tingkat kekerasan blok sangat tergantung pada komposisinya. Makin tinggi kandungan molases dan urea makin rendah kepadatannya. Bahan pemadat atau pengisi sangat penting untuk menghasilkan produk yang keras dan tergantung dari jenis bahan pemadatnya. Tingkat kekerasan blok juga dipengaruhi oleh jangka waktu penjemuran. Penjemuran selama 14-28 hari mampu membuat blok dengan bahan semen menjadi keras.

Pemahaman peserta terhadap materi dan pelaksanaan praktek pembuatan UMMB dapat dilihat pada Tabel 1.

Tabel 1. Pemahaman peserta terhadap materi dan pelaksanaan praktek pembuatan UMMB

\begin{tabular}{clccc}
\hline \multirow{2}{*}{ No } & \multirow{2}{*}{ Uraian } & \multicolumn{3}{c}{ Peternak } \\
\cline { 3 - 5 } & & Baik & Cukup & Kurang \\
\hline 1 & Pengertian UMMB & 5 & 10 & 5 \\
2 & Kegunaan UMMB & 5 & 12 & 3 \\
3 & Pemilihan bahan UMMB & 15 & 3 & 2 \\
4 & Teknik pembuatan UMMB & 15 & 3 & 2 \\
5 & Cara pemberian UMMB & 17 & 3 & 0 \\
6 & Keinginan peternak menerapkan teknologi & 10 & 5 & 5 \\
\hline
\end{tabular}

Berdasarkan Tabel 1 terlihat bahwa sebanyak $75 \%$ peserta sudah memahami dengan baik pemilihan bahan yang digunakan dalam pembuatan UMMB, dimana syarat bahan pakan yang dapat digunakan sebagai UMMB adalah mudah diperoleh dan harga murah, secara nutrisi tidak mengandung racun atau anti nutrisi, dan mengandung sumber energi, sumber protein dan sumber mineral. Produk UMMB yang dihasilkan memiliki konsistensi yang sedang (tidak keras dan tidak lunak). Menurut Yanuarto et al. (2019) tingkat kekerasan blok sangat tergantung pada komposisinya. Makin tinggi kandungan molases dan urea makin rendah kepadatannya. Bahan pemadat atau pengisi sangat penting untuk menghasilkan produk yang keras dan tergantung dari jenis bahan pemadatnya. Tingkat kekerasan blok juga dipengaruhi oleh jangka waktu penjemuran. Semen atau kapur merupakan komponen formulasi UMMB yang digunakan sebagai bahan perekat untuk mengikat semua bahan sebagai sumber kalsium/Ca (Antwi, 2014). Penggunaan 10 sampai 15\% semen atau kapur akan membuat UMMB menjadi keras tapi membahayakan ternak. Hasil penelitian Mohammed et al. (2007) dan Antwi (2014) menunjukkan bahwa tidak ada efek negatif dari semen saat diberikan sampai 1\% dari total asupan harian bahan kering. Pada kegiatan ini semen putih sebesar yang digunakan sebagai perekat UMMB sebesar 10\%. Menurut Aye (2005), penambahan semen sebanyak 10-15\% sebagai bahan pengikat dan pengeras pada UMMB tidak 
menimbulkan masalah pada ternak. Selain penggunaan semen, tanah liat dapat juga digunakan sebagai bahan perekat dalam pembuatan UMMB. Penelitian Omoniyi et al. (2013) menunjukkan bahwa penggunaan semen (10\%) sebagai pengikat dikombinasikan dengan tanah liat $(5 \%)$ terbukti efektif dan efisien sebagai bahan pengikat UMMB.

Hasil pengamatan terhadap sapi di Kelompok Tani Sumber Rezeki Karya Tani menunjukkan performans yang baik dan produk UMMB memiliki palatabilitas yang bagus karena disukai ternak sapi yang dipelihara oleh kelompok. Pada kegiatan ini tidak dilakukan penimbangan terhadap berat badan sapi yang mengkonsumsi UMMB, sehingga tidak diperoleh data tentang berat badan karena kegiatan ini lebih difokuskan pada pembuatan produk yang dihasilkan peternak yang tergabung dalam kelompok.

Secara keseluruhan pemahaman peternak terhadap produk UMMB setelah dilaksanakan pelatihan bekisar 75\%-85\%. Hal ini dapat digunakan sebagai indikasi bahwa kegiatan telah berhasil dan mendapat respon yang baik dari peternak. Sebanyak $50 \%$ peserta akan bersedia menerapkan teknologi ini (pembuatan UMMB) dengan syarat mereka mempunyai waktu luang yang lebih. rendahnya keinginan untuk menerapkan teknologi ini disebabkan karena peternak tidak ingin direpotkan dengan teknologi yang ada dan lebih memilih untuk memberikan hijauan pada ternak secara lanngsung.

\section{KESIMPULAN}

1. Peternak di Kelompok Tani Sumber Rezeki Karya Tani berhasil memahami dengan baik pemilihan bahan yang digunakan dalam pembuatan UMMB

2. Tingkat partisipasi peserta sangat baik dengan tingkat kehadiran berkisar $90-100 \%$.

\section{UCAPAN TERIMA KASIH}

Ucapan terimakasih disampaikan kepada Yayasan dan Universitas Islam Kalimantan melalui Lembaga Penelitian dan Pengabdian pada Masyarakat yang telah mendanai kegiatan P2M ini. Ucapan terimakasih juga disampaikan kepada anggota tim dan mahasiswa Prodi Peternakan Faperta UNISKA yang telah membantu pelaksanaan kegiatan ini.

\section{DAFTAR PUSTAKA}

Anonim. 2018. Profil Kelompok Sumber Rezeki Karya Tani. Banjarbaru.

Anonim. 2019. Banjarbaru dalam Angka. Badan Pusat Statistik Pemerintah Kota Banjarbaru. Banjarbaru. Hal. 36.

Antwi C. 2014. Small Ruminants Feed Improvement Handbook. Anwomaso. Prisebs Publishers Hal. 2-21.

Aye PA. 2005. Development of multinutrient blocks for the small ruminants in Nigeria. Proc $10^{\text {th }}$ Ann Conf ASAN: 195-196.

Evitayami W, Fariani A, Ichinohe T, Abdulrazak SA and Fujihara T. 2004. Comparative rumen degradability of some legumes forages between wet and dry season in West Sumatra, Indonesia. Asia-Australian J Animal Science 17: 1107-1111.

Focus. 2005. International Focus Information Centre For Small Scale Farmers in Asia: Philippines Council for Agriculture, Forestry and Natural Resources and Development (PCARRD) Los Banos, Laguna, 4030 The Philippines.

Hennessy DW. 1984. The role of Protein in Improving Production of Cattle Grazing NativePastures in Sub-tropical New South Wales. Ph.D Thesis Armidale- Australia. Univ. of New England.

Mohammed ID, Baulube M and Adeyinka IA. 2007. Multinutrient blocks 1: formulation and production undera semiarid environment of Nor th East Nigeria. Jo u rnal of Biological Sciences. 7(2): 389-392.

Nazir M. 1988. Metode Penelitian. Ghalia Indonesia. Jakarta. Hal 72-74. 
Nista D, Natalia H dan Taufik A. 2010. Teknologi Pengolahan Pakan. Direktorat Jendral Bina Produksi Peternakan. Palembang. Hal. 2-3.

Omoniyi LA, Isah OA, Adewumi OO, Arigbede OM and Onwuka CFI. 2013. Phy sico-Chemical Properties and Storability of Urea Molasses Multi NutrientFeed Block (UMMB) as Dry Season Supplement for Ruminants. Journal of Applied Agricultural Research. 5(1): 113-121.

Yanuartono, Soedarmanto I, Alfarisa N, Purnamaningsih H dan Raharjo S. 2019. Urea molasses multinutrien blok sebagai pakan tambahan pada ternak ruminansia Jurnal Veteriner. 20(3): 445-451. doi: 10.19087/jveteriner.2019.20.3.445. 